\title{
PENERAPAN MODEL PEMBELAJARAN TAKE AND GIVE BERBANTUAN MEDIA MENJEMUR KAOS BERBASIS PERMAINAN EDUKATIF UNTUK MENINGKATKAN HASIL BELAJAR MATEMATIKA KELAS II-A DI SDN-5 PANARUNG PALANGKARAYA TAHUN PELAJARAN 2016/2017.
}

\author{
Oleh : Agung Riadin, M.Pd. *Dan Kurnia Sari*
}

\begin{abstract}
Abstrak
Penelitian ini bertujuan untuk mengetahui: (1) Aktivitas belajar peserta didik dalam pembelajaran Matematika pada penerapan model pembelajaran Take and Give berbantuan media menjemur kaos berbasis permainan edukatif, dan (2) Peningkatan hasil belajar Matematika setelah penerapan model pembelajaran Take and Give berbantuan media menjemur kaos berbasis permainan edukatif.

Jenis penelitian ini adalah Penelitian Tindakan Kelas (PTK). Subjek penelitian adalah peserta didik kelas II-A di SDN-5 Panarung Palangkaraya yang berjumlah 29 orang peserta didik yang sekaligus dijadikan sampel penelitian. Pengumpulan data menggunakan observasi dan tes, sedangkan untuk teknik analisis data menggunakan teknik analisis ketuntasan klasikal dan individual.

Dari hasil penelitian disimpulkan bahwa: (1) Aktivitas peserta didik sangat baik dalam pembelajaran Matematika pada penerapan model pembelajaran Take and Give berbantuan media menjemur kaos berbasis permainan edukatif. Peserta didik berperan aktif, termotivasi, saling bekerjasama dengan meningkatkan kosentrasi dan kecepatan berpikir selama proses pembelajaran pada siklus I. Adapun hasil pengamatan aktivitas guru pada proses pembelajaran yang dilakukan oleh pengamat 1 dan pengamat 2 selama proses pembelajaran Matematika pada siklus I rata-rata aspek aktivitas guru yaitu 3,74 dengan kriteria sangat baik dan rata-rata aspek aktivitas peserta didik yaitu 3,55 dengan kriteria sangat baik, dan (2) Ada peningkatan hasil belajar belajar Matematika peserta didik setelah penerapan model pembelajaran Take and Give berbantuan media menjemur kaos berbasis permainan edukatif. Hal ini ditunjukkan dengan hasil belajar yang dilihat melalui skor rata-rata kelas pada siklus I yaitu 82 dengan kriteria tercapai dan memenuhi KKM 65, mencapai persentase ketuntasan belajar peserta didik secara klasikal yaitu $100 \%$, dengan kriteria ketuntasan klasikal $85 \%$. Dengan ini maka dapat disimpulkan bahwa ada peningkatan hasil belajar Matematika setelah menerapkan model pembelajaran Take and Give berbantuan media menjemur kaos berbasis permainan edukatif.
\end{abstract}

Kata Kunci: Hasil Belajar Matematika, Model Pembelajaran Take and Give, Permainan Edukatif dan Media Menjemur Kaos.

\section{PENDAHULUAN}

Dalam pendidikan formal (sekolah), pembelajaran merupakan tugas yang dibebankan kepada guru, karena guru merupakan tenaga professional yang dipersiapkan untuk itu. UU RI No. 20 tahun 2003 pasal 3 tentang sistem
Pendidikan Nasional yang menjelaskan bahwa pendidikan dilakukan untuk mewujudkan fungsi dan tujuan pendidikan nasional sebagaimana tertuang dalam pasal 3 yang menerangkan bahwa : Pendidikan Nasional berfungsi untuk mengembangkan 
kemampuan dan membentuk watak serta peradaban bangsa yang bermartabat dalam rangka mencerdaskan kehidupan bangsa, bertujuan untuk berkembangnya potensi peserta didik agar menjadi manusia yang beriman dan bertaqwa kepada Tuhan Yang Maha Esa, berakhlak mulia, sehat, berilmu cakap kreatif, mandiri dan menjadi warga yang demokratis serta bertanggung jawab.

Menurut pendapat Miarso (Siregar dan Nara, 2014: 12) menyatakan bahwa "pembelajaran adalah usaha pendidikan yang dilaksanakan secara sengaja, dengan tujuan yang telah ditetapkan terlebih dahulu sebelum proses dilaksanakan, serta pelaksanaannya terkendali." Namun sayangnya, sebagaimana dilaporkan oleh Raharjo (Susanto, 2013:93) menyebutkan bahwa dalam pembelajaran disekolah dasar saat ini, guru masih menganggap peserta didik sebagai objek, bukan sebagai subjek dalam pembelajaran, sehingga guru dalam proses pembelajaran masih mendominasi aktivitas belajar, akibatnya kemampuan peserta didik tidak maksimal dan hasil belajar tidak sesuai dengan yang diharapkan. Pelajaran Matematika merupakan salah satu komponen pendidikan dasar dalam bidang pengajaran.

Matematika merupakan salah satu pelajaran yang ada pada semua jenjang pendidikan, mulai dari tingkat sekolah dasar hingga perguruan tinggi. Piaget (Susanto, 2013:184) pada usia sekolah dasar (7-8 tahun hingga 12-13 tahun) menurut teori kognitif Piaget termasuk pada tahap operasional konkrit. Berdasarkan perkembangan kognitif ini, maka anak usia sekolah dasar pada umumnya mengalami kesulitan dalam memahami Matematika yang bersifat abstrak. Karena keabstrakannya pembelajaran Matematika relatif tidak mudah dipahami oleh peserta didik sekolah dasar pada umumnya.

Pembelajaran

Matematika merupakan suatu proses belajar mengajar yang mengandung dua jenis kegiatan yang tidak terpisahkan. Kegiatan tersebut adalah belajar dan mengajar. Kedua aspek ini akan berkolaborasi secara terpadu menjadi suatu kegiatan pada saat terjadi interaksi anatara peserta didik dengan guru, antara peserta didik dengan peserta didik, dan antara peserta didik dengan lingkungan disaat pembelajaran Matematika sedang berlangsung. Guru menempati posisi kunci dalam menciptaan suasana belajar yang kondusif dan menyenangkan untuk mengarahkan peserta didik mencapai tujuan secara optimal, serta guru harus mampu menempatkan dirinya secara dinamis dan fleksibel sebagai informan, tranformator, organiser, serta evaluator bagi terwujudnya kegiatan belajar yang dinamis dan inovatif. Secara umum tujuan pembelajaran Matematika disekolah dasar adalah agar peserta didik mampu terampil menggunakan Matematika.

Untuk mencapai tujuan pembelajaran Matematika tersebut, seorang guru hendaknya dapat menciptakan kondisi dan situasi pembelajaran yang memungkinkan peserta didik aktif membentuk, menemukan, dan mengembangkan pengetahuannya. Kemudian peserta didik dapat membentuk makna dari bahan-bahan pelajaran melalui suatu proses belajar dan mengontruksinya dalam ingatan yang sewaktu-waktu dapat diproses dan dikembangkan lebih lanjut. Namun, rendahnya hasil belajar Matematika masih menjadi masalah yang begitu umum di dunia pendidikan, hal ini menjadi alasan kuat perlunya perhatian dan penanganan serius terhadap proses pembelajaran Matematika. 
Rendahnya hasil belajar Matematika peserta didik tersebut, tentu banyak faktor yang menyebabkannya, misalnya tentang penerapan metode pembelajaran Matematika yang masih terpusat pada guru (teacher oriented), sementara peserta didik cenderung pasif. Faktor lainnya ialah penerapan model pembelajaran yang kurang bervariasi, dan kurangya pemanfaatan media pembelajaran. Sistem pengajaran yang demikian ini menyebabkan peserta didik kurang berpartisipasi aktif dalam pembelajaran, sehingga dikhawatirkan peserta didik tidak dapat meningkatkan aktivitas belajar Matematika untuk meningkatkan pengembangan kemampuannya. Permasalahan ini masih banyak kita temukan di sekolah-sekolah dasar khususnya di SDN-5 Panarung Palangkaraya.

Berdasarkan hasil pengamatan pada waktu observasi di SDN-5 Panarung Palangkaraya yang dilakukan pada bulan November 2016 sebanyak 3 kali, dalam proses pembelajaran Matematika dikelas II-A cenderung masih berpusat pada guru dan buku LKS. Sehingga berdasarkan hasil pengamatan masih banyak nilai peserta didik yang dibawah KKM. Selain itu, pembelajaran hanya terpaku dengan LKS. Guru lebih nyaman menggunakan LKS karena dinilai lebih praktis dan tidak merepotkan. Dalam proses pembelajaran, guru mendominasi proses pembelajaran dengan memberikan ceramah sedangkan peserta didik diminta untuk menyimak LKS sehingga peserta didik kelihatan masih tampak pasif. Media yang digunakan dalam proses pembelajaran berupa papan tulis dan LKS sebagai latihan soal kepada peserta didik dan belum adanya umpan balik dari guru kepada peserta didik pada proses pembelajaran. Hal ini menyebabkan banyak peserta didik menganggap proses pembelajaran Matematika adalah sesuatu yang membosankan, monoton, kurang menyenangkan, terlalu banyak hafalan, kurang variatif dan berbagai keluhan lainnya.

Hal tersebut di tunjukkan dengan 20 dari 29 peserta didik menganggap Matematika itu pelajaran yang sulit. Salah satu hal yang membuat mereka merasa mata pelajaran Matematika sulit adalah terletak pada hafalan dan pemahaman. Hal ini ditunjukkan dengan nilai yang masih dibawah KKM yang telah ditentukan pada mata pelajaran Matematika yaitu 65. Dari 29 peserta didik ada 20 peserta didik yang tidak mencapai KKM atau sebanyak $68,97 \%$.

Melihat kondisi yang seperti itu, perlu kiranya melakukan pengembangan dan peningkatan mutu dalam pembelajaran Matematika, yakni pembelajaran yang mampu mengoptimalkan interaksi setiap elemen untuk menumbuhkembangkan kemampuan berfikir. Guru selaku pendidik sudah melakukan pembelajaran dengan baik, hanya saja kurang mencoba hal yang baru dalam menggunakan pendekatan, media, metode maupun model pembelajaran.

\section{METODE PENELITIAN}

Penelitian ini menggunakan rancangan Penelitian Tindakan Kelas (PTK). PTK menurut Wibawa (Taniredja, 2010: 142) merupakan suatu penelitian yang mengangkat masalah-masalah aktual yang dihadapi oleh guru dilapangan. Penelitian tindakan adalah penyelidikan sistematis apapun yang dilakukan oleh para pendidik dengan tujuan mengumpulkan informasi tentang bagaimana sekolah-sekolah khusus 
beroperasi, bagaimana mereka mengajar, dan bagaimana peserta didik meraka belajar.

Kehadiranpenelitisangatdiperlukanda lamsetiapkegiatan di tempatpenelitiankarenapenelitiberperanseb agaiperencana, pelakanaantindakan, pengamat, reflektordansebagaipelaporhasilpenelitian. Sebagaisubjekpemberitindakan,

Dalampelaksanaanpenelitiantindakan kelasini yang menjadisubjekpenelitian adalahpesertadidik kelas II-A semester genap yang berjumlah29 orang. Terdiridari10pesertadidikperempuandan 19pesertadidiklaki-laki. Sedangkan yang Data yang dikumpulkandarisetiapsiklusakandianalisis menggunakan metode Mixed Methods atau metode gabungan antara kualitatif dan kuantitatif. Emzir (2012: 28) "metode gabungan merupakan salah satu pendekatan yang cenderung didasarkan pada paradigma pengetahuan pragmatik (seperti orientasi konsekuensi, orientasi masalah, dan pluralistik)". Pendekatan ini menggunakan strategi penelitian yang melibatkan pengumpulan data baik secara simultan maupun sequensial untuk memahami masalah penelitian sebaikData

kualitatifdiperolehdariaktivitasterhadappen elitidanaktivitasterhadappesertadidikdanre sponpesertadidikselama proses belajar rmengajardenganmenganalisishasilbelajar yang dilihatdalam proses belajarmengajarmenggunakanmodel pembelajaran Take and Give berbantuan HASIL DAN PEMBAHASAN

Data dari hasil penelitian ini berupa : 1) pengamatan aktivitas guru dan peserta didik 2) Hasil belajar Matematika penelitibertindaksebagaipengajaratau guru model

yang bertugasmembuatrancanganpelaksanaanpe mbelajaran sekaligusmenyampaikanbahan ajar selama proses pembelajaran. Di sampingitu, peneliti juga mengumpulkandanmenganalisis data sertasebagaipelaporhasilpenelitian.

menjadiobjekpenelitianadalah hasil belajarMatematika.

Pengumpulan data yang diperolehpadapenelitianinidilakukanmelal uipengamatan(observasi)

danteshasilbelajar.

baiknya. Pengumpulan data juga melibatkan pemerolehan baik informasi numerik (melalui instumen) maupun informasi teks, sehingga database akhir merepresentasikan baik informasi kuantitatif maupun kualitatif. Sedengakan menurut Creswell dan Plano (Sanjaya, 2012: 49) Menjelaskan Mixed Methods atau metode campuran adalah pedoman pada arah dari kumpulan analisis data dan gabungan dari penelitian kualitatif dan kuantitatif dalam banyak fase pada proses penelitian.

media menjemur kaos berbasis permainan edukatif.

Data kuantitatif berasal dari hasil tes yang diberikan pada setiap akhir siklus kegiatan. Hal ini dilakukan untuk mengetahui peningkatan hasil belajar peserta didik pada pendekatan yangditerapkan.

menggunakan model pembelajaran Take and Give berbantuan medi menjemur kaos berbasis permainan edukatif. 
1) Pengamatan aktivitas guru dan peserta didik.

\section{Tabel 1}

Rekapitulasi Data Pengamatan

\begin{tabular}{|l|l|l|}
\hline \multirow{2}{*}{ No } & \multirow{2}{*}{ Aktivitas } & Skor rata - rata \\
\cline { 3 - 4 } & & Siklus I \\
\hline 1 & Guru & 3,74 \\
\hline 2 & Peserta didik & 3,55 \\
\hline
\end{tabular}

Aktivitas guru dan peserta didik dapat dilihat pada tabel dan gambar berikut Observasi Aktivitas Guru dan Peserta didik

Tahun 2017 (Dua orang observer)

Berdasarkan tabel di atas, melalui pembelajaran menggunakan model pembelajaran Take and Give berbantuan media menjemur kaos berbasis permainan edukatif oleh peneliti di kelas II-ASDN 5Panarung Palangkaraya aktivitas guru dan peserta didik menunjukan suatu peningkatan yang baik dari observasi awal

2) Hasil belajar Matematika peserta didik menggunakan Model Pembelajaran

menjemur kaos berbasis permainan edukatif.

Take and Give berbantuan media

\section{Tabel 2}

Rekapitulasi Hasil Belajar Matematika Peserta didik kelas II-A

\begin{tabular}{|c|c|c|c|c|c|c|c|}
\hline $\begin{array}{l}\text { No } \\
\text {. }\end{array}$ & $\begin{array}{l}\text { Kode } \\
\text { Peserta } \\
\text { Didik }\end{array}$ & $\begin{array}{l}\mathbf{K K} \\
\mathbf{M}\end{array}$ & $\begin{array}{l}\text { Nilai } \\
\text { Pre- } \\
\text { test }\end{array}$ & Keterangan & $\begin{array}{l}\text { Nilai } \\
\text { Post- } \\
\text { test }\end{array}$ & $\begin{array}{l}\text { Kategor } \\
\text { i }\end{array}$ & $\begin{array}{l}\text { Kelemaha } \\
\text { n }\end{array}$ \\
\hline 1. & ESW & 65 & 60 & $\begin{array}{l}\text { Meningkat } \\
25\end{array}$ & 85 & $\mathrm{~T}$ & - \\
\hline 2. & NNF & 65 & 70 & $\begin{array}{l}\text { Meningkat } \\
20\end{array}$ & 90 & $\mathrm{~T}$ & - \\
\hline 3. & MP & 65 & 45 & $\begin{array}{l}\text { Meningkat } \\
25\end{array}$ & 70 & $\mathrm{~T}$ & - \\
\hline 4. & NRA & 65 & 85 & $\begin{array}{l}\text { Meningkat } \\
15\end{array}$ & 100 & $\mathrm{~T}$ & - \\
\hline 5. & $\mathrm{RZ}$ & 65 & 55 & $\begin{array}{l}\text { Meningkat } \\
20\end{array}$ & 75 & $\mathrm{~T}$ & - \\
\hline 6. & DJF & 65 & 80 & $\begin{array}{l}\text { Meningkat } \\
15\end{array}$ & 95 & $\mathrm{~T}$ & - \\
\hline 7. & $\mathrm{RS}$ & 65 & 75 & $\begin{array}{l}\text { Meningkat } \\
15\end{array}$ & 90 & $\mathrm{~T}$ & - \\
\hline 8. & $\mathrm{AZ}$ & 65 & 65 & $\begin{array}{l}\text { Meningkat } \\
15\end{array}$ & 80 & $\mathrm{~T}$ & - \\
\hline
\end{tabular}




\begin{tabular}{|c|c|c|c|c|c|c|c|}
\hline 9. & APP & 65 & 55 & $\begin{array}{l}\text { Meningkat } \\
20\end{array}$ & 75 & $\mathrm{~T}$ & - \\
\hline 10. & AS & 65 & 70 & $\begin{array}{l}\text { Meningkat } \\
25\end{array}$ & 95 & $\mathrm{~T}$ & - \\
\hline 11. & DS & 65 & 75 & $\begin{array}{l}\text { Meningkat } \\
10\end{array}$ & 85 & $\mathrm{~T}$ & - \\
\hline 12. & DRR & 65 & 45 & $\begin{array}{l}\text { Meningkat } \\
25\end{array}$ & 70 & $\mathrm{~T}$ & - \\
\hline 13. & $\mathrm{MH}$ & 65 & 40 & $\begin{array}{l}\text { Meningkat } \\
30\end{array}$ & 70 & $\mathrm{~T}$ & - \\
\hline 14. & HR & 65 & 60 & $\begin{array}{l}\text { Meningkat } \\
20\end{array}$ & 80 & $\mathrm{~T}$ & - \\
\hline 15. & RA & 65 & 70 & $\begin{array}{l}\text { Meningkat } \\
20\end{array}$ & 90 & $\mathrm{~T}$ & - \\
\hline 16. & RPA & 65 & 80 & $\begin{array}{l}\text { Meningkat } \\
20\end{array}$ & 100 & $\mathrm{~T}$ & - \\
\hline 17. & AMS & 65 & 50 & $\begin{array}{l}\text { Meningkat } \\
25\end{array}$ & 75 & $\mathrm{~T}$ & - \\
\hline 18. & AV & 65 & 40 & $\begin{array}{l}\text { Meningkat } \\
30\end{array}$ & 70 & $\mathrm{~T}$ & - \\
\hline 19. & $\mathrm{AF}$ & 65 & 55 & $\begin{array}{l}\text { Meningkat } \\
20\end{array}$ & 75 & $\mathrm{~T}$ & - \\
\hline 20. & ANC & 65 & 55 & $\begin{array}{l}\text { Meningkat } \\
15\end{array}$ & 70 & $\mathrm{~T}$ & - \\
\hline 21. & MHA & 65 & 50 & $\begin{array}{l}\text { Meningkat } \\
20\end{array}$ & 70 & $\mathrm{~T}$ & - \\
\hline 22. & MABN & 65 & 80 & $\begin{array}{l}\text { Meningkat } \\
15\end{array}$ & 95 & $\mathrm{~T}$ & - \\
\hline 23. & $\mathrm{ZR}$ & 65 & 70 & $\begin{array}{l}\text { Meningkat } \\
10\end{array}$ & 80 & $\mathrm{~T}$ & - \\
\hline 24. & $\mathrm{AB}$ & 65 & 75 & $\begin{array}{l}\text { Meningkat } \\
10\end{array}$ & 85 & $\mathrm{~T}$ & - \\
\hline 25. & $\mathrm{SH}$ & 65 & 60 & $\begin{array}{l}\text { Meningkat } \\
20\end{array}$ & 80 & $\mathrm{~T}$ & - \\
\hline 26. & $\mathrm{DF}$ & 65 & 60 & Meningkat15 & 75 & $\mathrm{~T}$ & - \\
\hline 27. & MRI & 65 & 55 & $\begin{array}{l}\text { Meningkat } \\
15\end{array}$ & 70 & $\mathrm{~T}$ & - \\
\hline 28. & BNP & 65 & 75 & $\begin{array}{l}\text { Meningkat } \\
10\end{array}$ & 85 & $\mathrm{~T}$ & - \\
\hline 29. & AI & 65 & 85 & $\begin{array}{l}\text { Meningkat } \\
15\end{array}$ & 100 & $\mathrm{~T}$ & - \\
\hline \multicolumn{2}{|c|}{ Jumlah } & & 1840 & $\begin{array}{l}\text { Meningkat } \\
540\end{array}$ & 2380 & & \\
\hline
\end{tabular}




\begin{tabular}{|l|l|l|l|l|}
\hline Nilai Rata-rata & \multirow{6}{*}{$\begin{array}{l}63 \\
\text { Ketuntasan }\end{array}$} & $\begin{array}{l}\text { Meningkat } \\
19\end{array}$ & 82 \\
\cline { 1 - 3 } Klasikal & & $\begin{array}{l}48,28 \\
\%\end{array}$ & $\begin{array}{l}\text { Meningkat } \\
51,73 \%\end{array}$ & $100 \%$ \\
\hline
\end{tabular}

Sumber Data : Penelitian

Tahun

2017

Gambar 1

Berdasarkan tabel hasil post test

Diagram

Hasil

pada siklus I terlihat hasil belajar peserta didik kelas II-A SDN 5Panarung Palangkaraya dengan rata-rata 82 dengan ketuntasan klasikal mencapai $100 \%$ ini berarti pada siklus ke I ketuntasan belajar individu sudah mencapai dan dianggap tuntas, jadi tidak perlu ada tindakan selanjutnya untuk memperbaiki hasil belajar karena, target dalam penelitian ini adalah standar KKM 65 sudah tercapai, dan tingkat ketercapaian ketuntasan hasil belajar peserta didik secara klasikalnya sudah melebihi target yang diinginkan, yaitu $85 \%$.

\section{Rekapitulasi Nilai Rata-Rata dan Ketuntasan}

\section{Hasil Belajar Matematika Peserta Didik Kelas II-A SDN 5 Pahandut Palangka Raya}

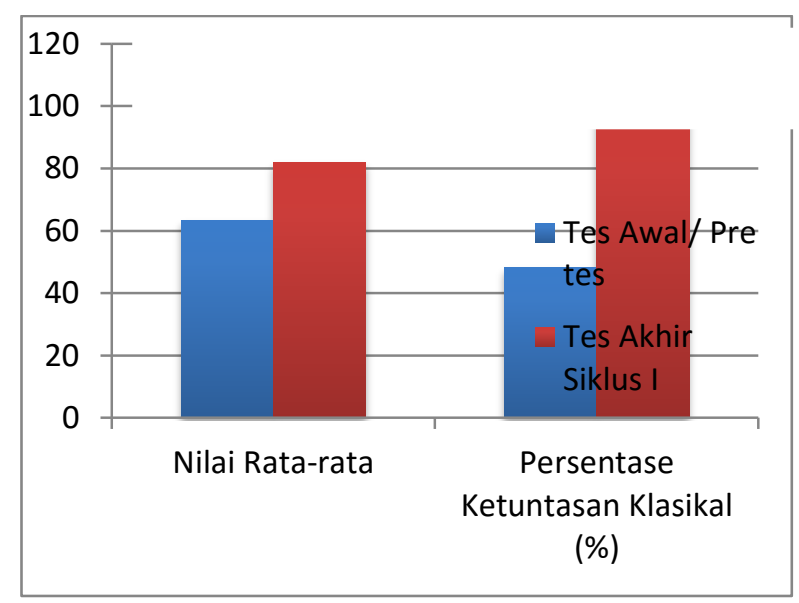

\section{SIMPULAN}

Berdasarkan hasil penelitian yang telah dibahas maka dapat disimpulkan:

1. Aktivitas belajar peserta didik kelas IIA di SDN-5 Panarung Palangkaraya sangat baik pada saat pembelajaran Matematika dengan penerapan model pembelajaran take and give berbantuan media menjemur kaos berbasis permainan edukatif, karena peserta didik aktif, antusias, mendengar penjelasan guru serta bersemangat dalam mengikuti proses pembelajaran. Skor rata-rata yang diperoleh peserta didik adalah 3,55 dengan kriteria sangat baik. Peserta didik aktif dalam mengikuti proses pembelajaran, hasil yang diperoleh mencapai indikator ketercapaian yang telah ditetapkan, sehingga dikatakan berhasil.

2. Terdapat peningkatan hasil belajar Matematika peserta didik kelas II-A di SDN-5 Panarung Palangkaraya dengan penerapan model pembelajaran take and give berbantuan media menjemur kaos berbasis permainan edukatif. Tes awal nilai rata-rata peserta didik yang diperoleh adalah 63 dan ketuntasan klasikal 48,28\%. Nilai rata-rata setelah penerapan model pembelajaran take and give berbantuan media menjemur kaos berbasis permainan edukatif meningkat yaitu, 82 dan ketuntasan klasikalnya $100 \%$. Penerapan model pembelajaran take and give berbantuan media menjemur kaos berbasis permainan edukatif ini diterapkan pada pembelajaran Matematika untr ${ }^{-1}$ mengembangkan kemampuan peser 88 didik dalam mengingat dan memahami pelajaran baik secara individu maupun kelompok. 
DAFTAR PUSTAKA

Emzir. (2012). Metodologi Penelitian Pendidikan Kualitatif dan Kuantitatif. Jakarta: PT. RajaGrafindo Persada.

Sanjaya, Wina. (2012). Media Komunikasi Pembelajaran. Jakarta:Kencana Prenadamedia Group.

Siregar, Eveline dan Hartini, Nara. (2014). Teori Belajar dan Pembelajaran. Bogor: Ghalia Indonesia.
Susanto, Ahmad. (2013). Teori Belajar dan Pembelajaran diSekolah Dasar. Jakarta: Kencana Prenada Media Group.

Taniredja, Tukiran, dkk. (2010). Penelitian Tindakan Kelas Untuk Pengembangan Profesi guru. Bandung: Alfabeta, CV. 